\title{
THE ACCURACY OF THE EQUITY'S FORECAST IN THE OPTION MODEL SIMULATED BY REAL VOLATILITY DISTRIBUTION
}

\author{
Zbigniew Krysiak \\ Warsaw School of Economics \\ e-mail: ZKrysiak@sgh.waw.pl \\ ORCID: 0000-0002-5894-7075 \\ (C) 2021 Zbigniew Krysiak \\ This work is licensed under the Creative Commons Attribution-ShareAlike 4.0 International License. \\ To view a copy of this license, visit http://creativecommons.org/licenses/by-sa/4.0/
}

Quote as: Krysiak, Z. (2021). The accuracy of the equity's forecast in the option model simulated by real volatility distribution. Financial Sciences, 26(1).

DOI: $10.15611 /$ fins.2021.1.03

JEL Classification: C10, C50

\begin{abstract}
The article is devoted to the assessment of the accuracy of the binomial model in forecasting the value of capital using the Back-Test approach. In this study, the Monte Carlo method was used to simulate the value of capital using real volatility distributions of stock returns. Based on the analysis of the variability of the stocks returns profile, a generator of real distributions was built, which was used for the Monte Carlo simulation. The results of the study confirmed the high quality and accuracy of the method proposed by the author. Due to the potentially large benefits for company management and investors that come from the measurement quality, according to the methodology presented in the study, it is worth extending this trend in theory and practice. This article is mainly directed to business practitioners engaged in the analytical process of company valuation in restructuring, merging and acquisition of enterprises, and building an investment portfolio.
\end{abstract}

Keywords: option model, binominal model, Monte Carlo simulation, real volatility distribution, Back-Test, forecast of the enterprise equity.

\section{Introduction}

Making business decisions in the process of strategy formulation and investing in the shares of a given company requires long-term business forecasting in the perspective of several years ahead, therefore measuring the growth in the company's value resulting from the taken actions and the impact of the economic environment is crucial in assessing the achievements of the company's strategic goals, what very much suggests the investor's decisions. Due to the stochastic nature of business, applying certain deterministic methods is not suitable for forecasting the effects of 
an enterprise's operation and its value. Therefore, the question arises what tools and models can best anticipate the future value of shareholders' capital, taking into account the development processes of the company and the environment's impact on it.

During the process of evaluating the acceptability of an investment project, the traditional discounted cash flow method presume that the company will hold its assets passively and ignore the need for adjustments which the company should make after the project has been accepted and implemented. Adjustments which allow for the flexibility of changing earlier decisions when project-related conditions change, are known as real options. The term 'real option' was introduced by S. Myers in 1977, according to whom the evaluation of investment possibilities using the net present value method ignores the value of the option which arises from the uncertainty which is inevitable in every project. A decade later, the real option method was applied in investment decision-making, partly due to the contribution of numerous authors, such as: Dixit and Pindyck (1995), Smit and Trigeorgis (2006), Cox, Ross and Rubinstein (1979), Mun (2002).

The Discounted Cash Flow (DCF) method for company valuation is not a prognostic tool, and by its nature does not take into account the random processes that are used to model the behaviour of stock prices, and thus the value of investors' capital. DCF is, in a sense, focused on expectations of future cash flows, and on that basis they are discounted to determine the present value. In contrast to that binomial model, otherwise known as the option model, observing the process of volatility in rates of return on share prices forms the basis for determining the future distribution of the share's capital value. This distribution creates the basis for determining its range in the future in the assumed time horizon. Such features of this methodology create a strong basis for its application from the perspective of logic and consistency with the nature of the economic and real financial processes in place. Such a model may therefore be acceptable in terms of quality, while the only question that remains is what would be its prognostic accuracy, and arising from that, the error in assessing the future value of equity.

The aim of this article was to present the application of the binomial model (BM) to forecast the value of equity using the real distribution of the volatility and the Monte Carlo simulation to assess the accuracy of the BM by applying the Back-Test method for the companies listed on the Warsaw Stock Exchange. Hence in this research the author presented a new method for the forecasting of the equity and company value, which is embraced by the Binominal Model Simulated by the Real Volatility Distribution, reflected in the abbreviation, BIMSERVED.

In the process of achieving the research goal, the following hypothesis was formulated: BIMSERVED may allow to forecast the company's equity in the medium and long-term with high accuracy.

Real volatility distribution, obtained from the historical time series of the stock prices, was used instead of flat volatility. 
Many research papers usually indicate the DCF model as the appropriate tool to create the input value for the Binominal Model as the present value of the discounted cash flow, which is a Free Cash Flow to the Firm FCFF (Copeland \& Antikarov, 2001, p. 7; Mukhtar \& Agarwal, 2009; Mun, 2002; Samis \& Davis, 2014; Tomas \& Višić, 2020). No research paper applying the approach was found by the author, where the BIMSERVED model in the research assumes that the initial value of the company is equal to the sum of debt in the balance sheet and the market value of equity. The author believes that the input used is probably more accurate and reflects well the real value.

Some studies apply the Monte Carlo simulation to forecast the cash components or estimate the revenue of an enterprise (Copeland \& Antikarov, 2001, p. 7; Hussain, 2019; Samis \& Davis, 2014; Tomas \& Višić, 2020) whilst they do not use real distributions of cash flows but a standard one delivered by, for instance, software such as Cristal Ball.

Other papers used the Monte Carlo simulation for corporate valuation. These models combined several valuation methods in order to obtain more accurate results. To determine the corporate asset value, the authors used the Gordon-type two-stage asset valuation model based on the calculation of the free cash flow to the firm, as well as the free cash flow to the firm to determine the corporate market value, and then calculated with use of the Black-Scholes option pricing model in the framework of the two-dimensional Monte Carlo simulation method. The combined model and the use of the two-dimensional simulation model naturally provided a better quality for the corporate value estimation (Copeland \& Antikarov, 2001, p. 7; Fenyves \& Tarnoczi, 2010; Samis \& Davis, 2014; Tomas \& Višić 2020), but they did not use the real distributions, which significantly reduced the quality.

In the BIMSERVED model, the real volatility distribution was obtained from the historical time series of the stock prices, and were used instead of flat volatility, what was the case in other research papers.

The binominal model is frequently applied for the appraisal of investment projects, which is then called the Real Option Model (ROM). There are applications of BM for forecasting the value of a company with flat volatility over the forecasted horizon and it delivers only one expected value, which means that real volatility's distribution is not applied, and no Monte Carlo Simulation (MCS) is used. To the best of the author's knowledge, no applications of BM exist which combine the real volatility distributions (RVD) and MCS to Back-Test the forecasting accuracy, hence this paper contributes to filling the research gap in this area.

The stock prices of ten companies from the Warsaw Stock Exchange were collected to verify the stated in the paper hypothesis: Wawel, Dębica, Apator, Amica, Stalprodukt, Żywiec, Ropczyce, Śnieżka, Budimex, and KGHM. The enterprises taken into consideration come from different branches, such as food production, construction, household equipment, the car industry, raw materials production, energy equipment, and raw materials for construction purposes. 


\section{Critical DCF analysis compared to BM in the context of value forecasting}

The BM or Real Option Model can be applied for the appraisal of an investment project. The most frequently used method for the evaluation of investment projects was the DCF concept, in which the decision is based on NPV or IRR. There are several disadvantages of the DCF method, listed in Table 1. The realities are contradictory to the DCF assumptions, and it seems that the BM (ROM) is able to address appropriately these deficiencies of the DCF model.

The application of the option model for a project's evaluation does not ensure the complete success of the project's development, but creates more flexibility in selecting different alternatives during the project's life cycle. The option methodology enables timely and more detailed recognition of the risk factors, which helps in the risk mitigation by transferring it to the other parties. The ROM shows increasing popularity in the Enterprise Risk Management, because of its feature of being able to combine, within the analytical process, many perspectives both strategic and operational by delivering very detailed conclusions about the behavior of different risk drivers and their impact on the global consolidated risk. The ROM requests to decompose the uncertainty sources by reflecting them in specific measures, like the mean value and the standard deviation of certain risk driving the cost, revenue, interest rate or other value's driving factors.

The main benefits of using the ROM in the project appraisal is its logic coherence with the business agreements signed by parties contributing to the project and the coherence with the character of the decision process. The ROM simulates optional decisions and estimates the outcomes based on different assumptions. The flexibility of the ROM, as opposed to the DCF methodology, is associated with the variety of options which can be combined into the portfolio and each option can affect the project at any time or sequentially over the period of the project.

The main concept in the option model is bound to the consideration regarding the difference between incoming cash flow (revenue or underlying assets value) from the project and the outgoing cash flows (financial expenditures or exercise price). Based on the result of that consideration, the decision about project implementation is postponed in time, or the project development is split into stages. In the DCF model, the decision is based on the NPV and usually the entire investment outlay is made at the very beginning of the project. Therefore, there is almost no space to protect the losses in the future, if some risk factors were not identified or well quantified, since no flexibility for such a decision in the DCF approach is anticipated. The option states the right to perform some actions in the future and having the right to income sources, without the obligation to invest continually. Purchasing the option, and possession of the limited time rights to exercise it, relates to a certain financial 
Table 1. Disadvantages of DCF assumptions versus realities and responces of ROM

\begin{tabular}{|c|c|c|}
\hline DCF Assumptions & Business Realities & Real Options Model Potentials \\
\hline $\begin{array}{l}\text { Decisions are made now, } \\
\text { and cash flow streams are } \\
\text { fixed for the future. }\end{array}$ & $\begin{array}{l}\text { Uncertainty and variability in } \\
\text { future outcomes. Not all decisions } \\
\text { are made today, as some may } \\
\text { be deferred to the future when } \\
\text { uncertainty becomes resolved. }\end{array}$ & $\begin{array}{l}\text { ROM considers variability of } \\
\text { cash flow, and decisions can be } \\
\text { spread over time depending on the } \\
\text { outcome. }\end{array}$ \\
\hline $\begin{array}{l}\text { Projects are "mini } \\
\text { firms", and they are } \\
\text { interchangeable with } \\
\text { whole firms. }\end{array}$ & $\begin{array}{l}\text { With the inclusion of network } \\
\text { effects, diversification } \\
\text { interdependencies, and synergy } \\
\text { firms, there are portfolios of projects } \\
\text { and their resulting cash flows. }\end{array}$ & $\begin{array}{l}\text { ROM supports the estimation of } \\
\text { consolidated volatility composed } \\
\text { of all projects to make decisions } \\
\text { for the portfolio perspective. }\end{array}$ \\
\hline $\begin{array}{l}\text { Once lunched, all } \\
\text { projects are passively } \\
\text { managed. }\end{array}$ & $\begin{array}{l}\text { Projects are usually actively } \\
\text { managed through the projects' } \\
\text { life cycle, including checkpoints, } \\
\text { decision options, budget constraints, } \\
\text { etc. }\end{array}$ & $\begin{array}{l}\text { ROM mainframe incorporates } \\
\text { adequate flexibility focused on } \\
\text { project development instead of } \\
\text { passive project implementation. }\end{array}$ \\
\hline $\begin{array}{l}\text { Future free cash } \\
\text { flow streams are all } \\
\text { highly predictable and } \\
\text { deterministic. }\end{array}$ & $\begin{array}{l}\text { It may be difficult to estimate future } \\
\text { cash flows as they are usually } \\
\text { stochastic and risky in nature. }\end{array}$ & $\begin{array}{l}\text { The fundamental principle of } \\
\text { the ROM concept relies on the } \\
\text { stochastic nature of the asset } \\
\text { value at the time. }\end{array}$ \\
\hline $\begin{array}{l}\text { Project discount rate } \\
\text { used is the opportunity } \\
\text { cost of capital, which is } \\
\text { proportional to non- } \\
\text { diversifiable risk. }\end{array}$ & $\begin{array}{l}\text { There are multiple sources of } \\
\text { business risks with different } \\
\text { characteristics, and some are } \\
\text { diversifiable across projects or time. }\end{array}$ & $\begin{array}{l}\text { The components of sources } \\
\text { of uncertainties due to their } \\
\text { correlations can be diversified } \\
\text { away, and this effect can be } \\
\text { recognized applying the ROM } \\
\text { methodology. }\end{array}$ \\
\hline $\begin{array}{l}\text { All risks are completely } \\
\text { accounted for by the } \\
\text { discount rate. }\end{array}$ & $\begin{array}{l}\text { Firm and project risk can change } \\
\text { during the course of the project. }\end{array}$ & $\begin{array}{l}\text { The ROM shows high flexibility } \\
\text { taking into account the risk } \\
\text { changing over the project and } \\
\text { business cycles. }\end{array}$ \\
\hline $\begin{array}{l}\text { All factors that could } \\
\text { affect the outcome of the } \\
\text { project and value to the } \\
\text { investors are reflected in } \\
\text { the DCF model through } \\
\text { the NPV or IRR. }\end{array}$ & $\begin{array}{l}\text { Due to the projects' complexity and } \\
\text { so-called externalities, it may be } \\
\text { difficult or impossible to quantify } \\
\text { all factors in terms of incremental } \\
\text { cash flows. Distributed, unplanned } \\
\text { outcomes (e.g. strategic vision } \\
\text { and entrepreneurial activity) can } \\
\text { be significant and strategically } \\
\text { important. }\end{array}$ & $\begin{array}{l}\text { The ROM approach is designed } \\
\text { to anticipate and incorporate } \\
\text { different strategic outcomes, } \\
\text { but they should be reflected in } \\
\text { forecasted cash flow and risk } \\
\text { uncertainties to determine for } \\
\text { ROM, the initial value and the } \\
\text { volatility impacting the project } \\
\text { value. }\end{array}$ \\
\hline $\begin{array}{l}\text { Unknown, intangible, or } \\
\text { immeasurable factors are } \\
\text { valued at zero. }\end{array}$ & $\begin{array}{l}\text { Many of the important benefits } \\
\text { are intangible assets or qualitative } \\
\text { strategic positions. }\end{array}$ & $\begin{array}{l}\text { Although intangible assets cannot } \\
\text { be reflected in cash flow, this can } \\
\text { be revealed in the volatility of } \\
\text { ROM. }\end{array}$ \\
\hline
\end{tabular}

Source: the first two columns of Table 1 (Mun, 2002), and the third column (own work). 
contribution which is much lower than the amount of the potential investment to start the project. Added value of the project can be given by Formula 1:

$$
C=V-K,
$$

where: $C$ - option value or premium-paid to purchase the rights connected to the option, $V$ - value of the cash income associated with the project when the option is exercised, $K$ - investment outlays incurred when the option is exercised (project implementation).

The project implementation generates the cash flow which creates the income and impacts on the value of the project over time. The project is aimed to create an additional value exceeding the value of the initial investments. The volatility of different uncertainty sources drives the chance to outweight the incoming cash over expenditures, and this can happen within the time horizon of the project's life cycle. The ROM model suggests that the volatility driven by different risk factors involved in the project plays a key role in the value creation. These risk factors include, but are not limited to, the fluctuations in the price-level, changes in the interest rates, inconstant demand for the product on the market, alterations in the cost of raw materials and the cost of energy, or unstable customers' preferences. The option model delivers substantial support in analysis and monitoring the risk factors for comparative studies in risk levels between the sectors in the economy (Jajuga \& Krysiak, 2005).

The risk in some certain way creates the value. The author would like to state that the risk is a carrier of the value and points to the spots of the value. The risk and opportunity created in the project development are inseparable; the enterprise cannot manage risk by limiting its exposure to the risk, as this would mean the simultaneous limitation or elimination of the opportunity (Antikarov, 2012, p. 4). The value is hidden until it is not observed through the optics of the volatility of risk factors. For that reason, the application of the volatility for discovering, identifying, and measuring the value seems to be an integral or inherent and necessary tool for the adequate detection of the value. The funding of the projects can be performed by equity and levered by attracting other kinds of debt from bank loans, or issuing bonds. Hence, the volatility used in an option analysis $\left(\sigma_{V}\right)$ should be adjusted to discount this leverage effect by dividing the volatility in equity prices $\left(\sigma_{E}\right)$ by $(1+D / E)$, where $D / E$ is the debt-to-equity ratio of the public firm. The project evaluation in the ROM utilizes the volatility of the project value, which can be calculated based on the following formula:

$$
\sigma_{V}=\frac{\sigma_{E}}{1+D / E} .
$$

The volatility of equity is calculated based on the stock returns. Another way to calculate the project's volatility is to apply the Monte Carlo simulation to the 
incoming cash flow anticipated in the project. It is very useful to combine the application of the option model with DCF (Krysiak, 2015), which delivers additional higher quality to the DCF and the final quality in the project's assessment. The estimation of the volatility, applied for ROM, from the DCF model supported by the Monte Carlo simulation goes through the following stages (Krysiak, 2015, p.2):

- Building the DCF model by selecting the appropriate cash flow items and discount rate.

- Identifying the key uncertainty sources such as: quantity of products sold, cost of raw materials, costs of sales.

- Assigning to each risk driver a distribution adequate to the nature and character of the specific risk type.

- Creating a model in Excel spread sheet simulating from 1000 up to 5000 different present values of cash flow, originating from the DCF model.

- Calculating the following basic parameters of the distribution obtained from the Monte Carlo simulation: minimum value, maximum value, average value, standard deviation and volatility (standard deviation/average value).

\section{Evolution of the company value based in the BM}

The distribution of the enterprise value obtained in the BM is a consequence of the assumed stochastic process of the assets value. The changes in the assets value follow the stochastic process of Brownian motions. The basics for that concept were created by Ito, and later by Black, Scholes and Ross. The value of the assets at any time is derived from the stochastic process which is composed of two items. The first

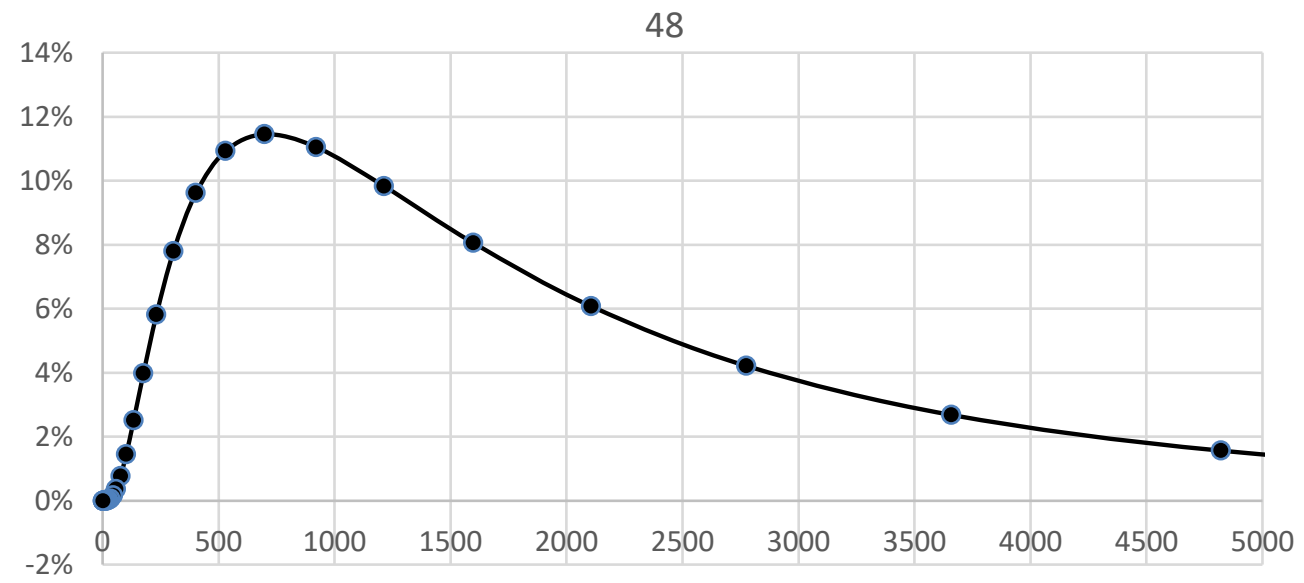

Fig. 1. Log-normal distribution of assets value in the Binominal Model (the vertical axis shows the density of probability and the horizontal axis the value of the company)

Source: own work. 
component drives the constant increase in the assets value and the second is the random one. If the value of assets at time $t_{0}$ equals $V_{0}$, then the value of the assets at time $t_{0}+t$ will change by an amount depending on the value of drift and the random component. The random component is associated with the volatility which characterizes the nature of the assets under consideration. The volatility incorporates many sources driving the value of the assets and therefore it can be meant as an integrated measure of all risk drivers impacting on the company value. In fact the value distribution of assets at any time in the future is driven by the volatility factor. The procedure in deriving the assets value in general is common for all types of assets, but specific for each asset is the volatility, which should be estimated with particular attention since this factor impacts on the assets value. The log-normal distribution of the assets in this model means that no negative values are possible and there is overwhelming tendency to the high values. Figure 1 presents an example of assets distribution in the Binominal Model.

Figure 1 presents an example of the log-normal distribution of assets value in the BM. After 48 periods or 8 years, the assets' value tends strongly towards the maximum of 5000. The changes of assets' value in the BM follows the stochastic equation presented in Formula 3.

$$
d V=V \mu d t+V \sigma \varepsilon \sqrt{d t}
$$

where: $V$-value of assets; $\mu$-growth rate; $\sigma$-volatility; $t$ - time of one step in the $\mathrm{BM} ; \varepsilon$ - random factor following normal standard distribution, frequently denoted as $N(0,1)$ with expected value equal to 0 and standard deviation equal to 1 .

Integrating both sides of Equation 3, Formula 4 was obtained.

$$
V_{t}=V_{0} e^{\mu t+\sigma \varepsilon \sqrt{t}}
$$

where: $V_{0}-$ nitial value of assets at the beginning of the forecast in the Binominal Model.

Next, Equation 4 can be transformed into Formula 5.

$$
V_{t}=V_{0} e^{\mu t} e^{\sigma \varepsilon \sqrt{t}}
$$

Formula 5 can be decomposed into two parts: the first one $e^{\mu t}$ is called the deterministic component, the second one $e^{\sigma \varepsilon \sqrt{t}}$ a stochastic part. In the option model, component $e^{\mu t}$ is often equal to the rate of return on risk-free assets. This is due to the fact that the option model assumes that the factor that expresses the risk is volatility, and therefore it is no longer taken into account for the trend. The DCF rate of return (trend) contains a risk factor that is often difficult to read and verify. In this regard, the option model is more transparent. In one unit of time the deterministic part will increase the asset's value by equal rate $\mu$, but the stochastic component will 
increase or decrease the asset's value depending on the random variable generated by normal standard distribution.

Figure 2 illustrates the changes of the asset's value according to the assumed stochastic process. Without the random component the process would be reflected only by the straight rising line. The characteristic feature of such a stochastic process means that the value of assets in the next period depends on current values and not on the historical ones. In other words, the historical factors are reflected in the current price so that the history does not influence the future. The DCF concept estimates the value of assets based on the cash flow anticipated in the future, but the BM does the opposite based on the initial value of assets. The value in the following periods assumes the same procedure for all types of assets.

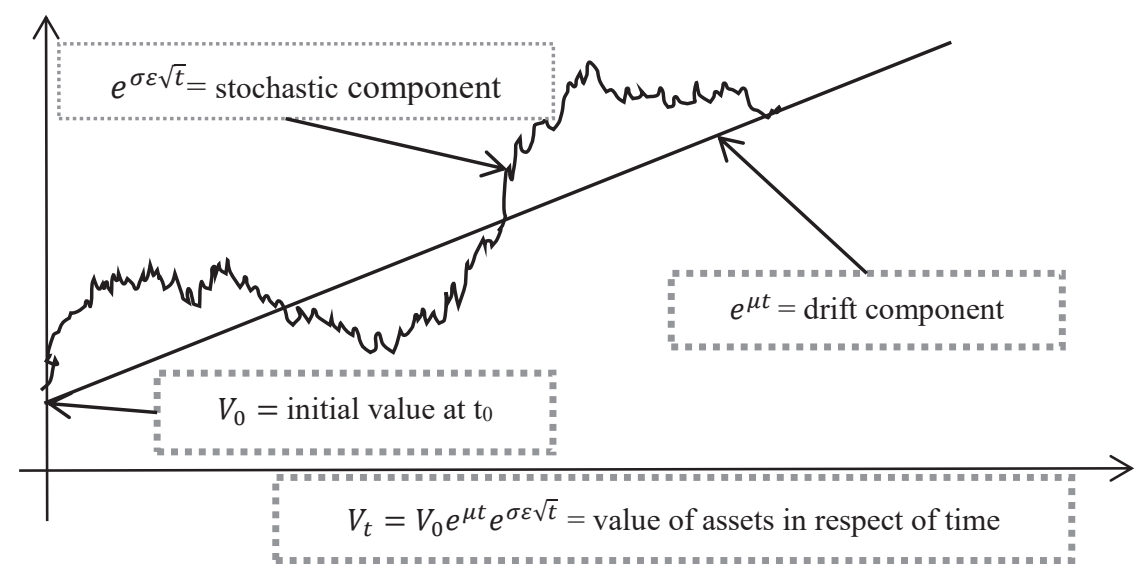

Fig. 2. The stochastic process of changes in assets' value

Source: own work.

One can show the relative changes in assets value over a short period of time as presented in Formula 6.

$$
\frac{\Delta V}{V}=e^{\mu t} e^{\sigma \varepsilon \sqrt{t}}
$$

Hence the growth rate, due to the random component, equals $u=e^{\sigma \sqrt{t}}$, and the decline rate equals $d=e^{-\sigma \sqrt{t}}$. Independently of the random change, the assets values continuously grow in the annual rate of $\mu$. Figure 3 presents the idea of the evolution of the value in the BM and its computation at the end of the tree.

To construct the graph in Figure 1, one needed to calculate the value, which is on the horizontal axis, and the probability, shown on the vertical axis. The procedure to determine the probability at the end of the tree is shown in Figure 4. 




Fig. 3. The evolution of the value in the $\mathrm{BM}$ and its computation at the end of the tree Source: own work

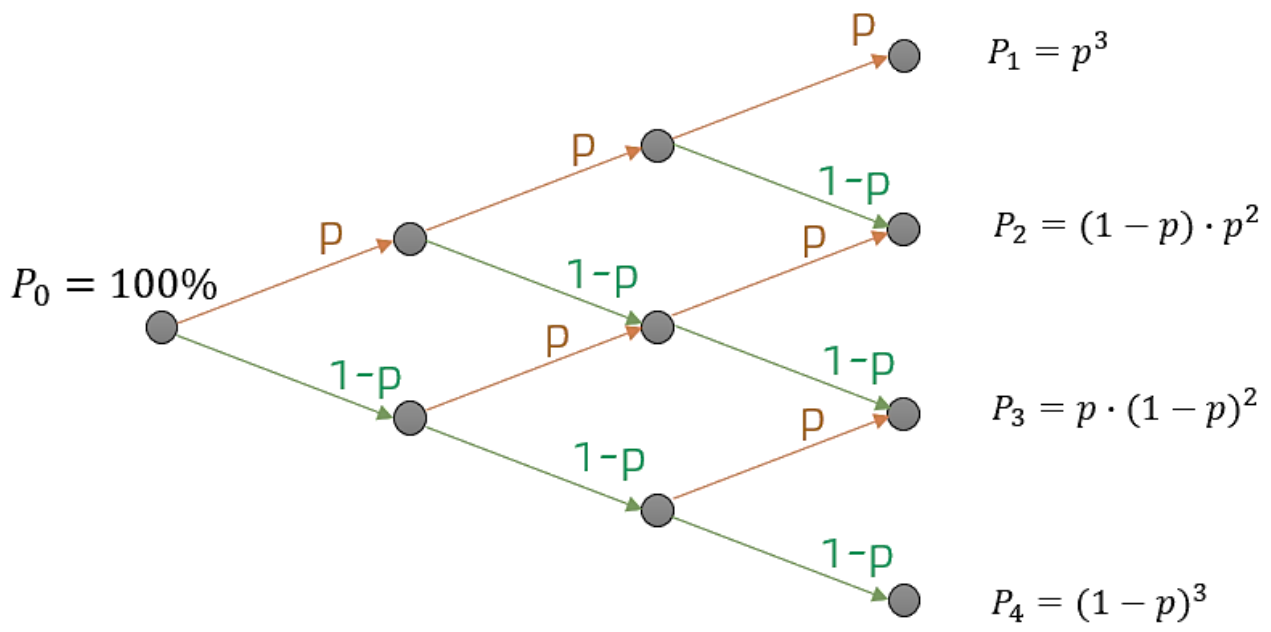

Fig. 4. Determining the probability to approach any final node at the BM tree

Source: own work.

In Figure $4(p)$ denotes the probability of the growth rate, and $(1-p)$ denotes the probability of the decline rate in each stage of the BM tree. The probability of the growth rate is given in Formula 7.

$$
p=\frac{e^{\mu t}-d}{u-d}
$$




\section{The methodology of the research study}

The aim of the study was to determine exactly how a company's equity value estimated in the binomial model, corresponds to the actual value quoted on the stock exchange. Ten companies from the Warsaw Stock Exchange were selected for the study. The stock prices and other financial data of these companies were obtained for the period from the beginning of 2005 to the end of 2020. The following companies were selected for the research: Wawel, Dębica, Apator, Amica, Stalprodukt, Żywiec, Ropczyce, Śnieżka, Budimex, and KGHM. They come from different branches such as food production, construction, household equipment, the car industry, raw materials production, energy equipment, and raw materials for construction purposes. These are big and medium sized companies established in Poland but operating on different European and world markets. The sample of companies was not randomly chosen, as the aim was to have a certain representation of the various industries. The research is a kind of pilot study to initially verify the research method and model, which justifies the small number of companies in the research sample. Such a limited approach in selecting companies was due to the author's goal of making scientific contribution mainly through building the procedure, which at the same time utilizes the option model, the Monte Carlo simulation, the generator for real distributions of volatility, and the Back-Test method for forecasting equity value. It seems that the author's model proved to be fairly effective.

The study applied the Back-Test method. A forecast of the distribution of the equity value was obtained in the horizon of 8 years up to the end of 2019, from the viewpoint of the end of 2011. With regard to the obtained equity distribution at the end of 2019, it was checked whether the value of equity quoted on the WSE for a given company was within the distribution range or not. The distance of the market equity from the boundaries of the modelled distribution was treated as the basis for estimating the relative error. The binomial model was supplied with data obtained at the beginning of 2012 which included: the actual distribution of the standard deviation of rates of return $\left(\sigma_{E}\right)$ on the prices of shares listed on the WSE based on the period from the beginning of 2005 to the end of 2011, the value of total liabilities in the company's balance sheet at the end of $2011\left(D_{0}\right)$, market value of capital at the end of $2011\left(E_{0}\right)$, forecast of the annual growth rate of liabilities $\left(R_{L}\right)$, cost of the loan as an interest rate on treasury bonds $(r)$. Based on the real distribution of the standard deviation of the rates of return $\left(\sigma_{E}\right)$, a generator was built to simulate Monte Carlo, in order to obtain the distributions of the company's capital value. Using the Ito lemma and the actual distribution of $\left(\sigma_{E}\right)$, the actual distribution of rates of return of the company's value was estimated $\left(\sigma_{V}=\sigma_{E} \frac{E_{o}}{V_{o}}\right)$. A binomial model was built in Excel and on its output the distributions of the capital value in four-time horizons, namely 2, 4, 6 and 8 years. For each of these horizons, the accuracy of the forecast was assessed in relation to the value of the publicly traded capital $\left(E_{M}\right)$. Accuracy as a relative error was determined on the basis of Formulas 8 and 9. If the market value 
was above the maximum value of the distribution, then the error (EOR) was determined from the formula (8), and if the market value was below the minimum value of the distribution, then the error (EUR) was determined from formula (9).

$$
\begin{gathered}
E O R=\frac{E_{M}-E_{\text {max }}}{E_{\text {max }}}, \\
E U R=\frac{E_{M}-E_{\text {min }}}{E_{\text {min }}},
\end{gathered}
$$

where: $E_{\min }-$ minimal value of the equity from the distribution, $E_{\max }-$ maximal value of the equity from the distribution, $E_{M}-$ value of the market equity.

Moving average 100 days (MA100) analysis of the volatility was used to better reflect the profile of the volatility changes over time and observe the intervals of cycles. Visual analysis of moving average volatility over time allows to infer about the character of the distribution of the volatility. An example of the MA100 for the Apator company is presented in Figure 5, which implies that one can expect a very asymmetric distribution.

Sigma Roczna MA(100) 2005-2011

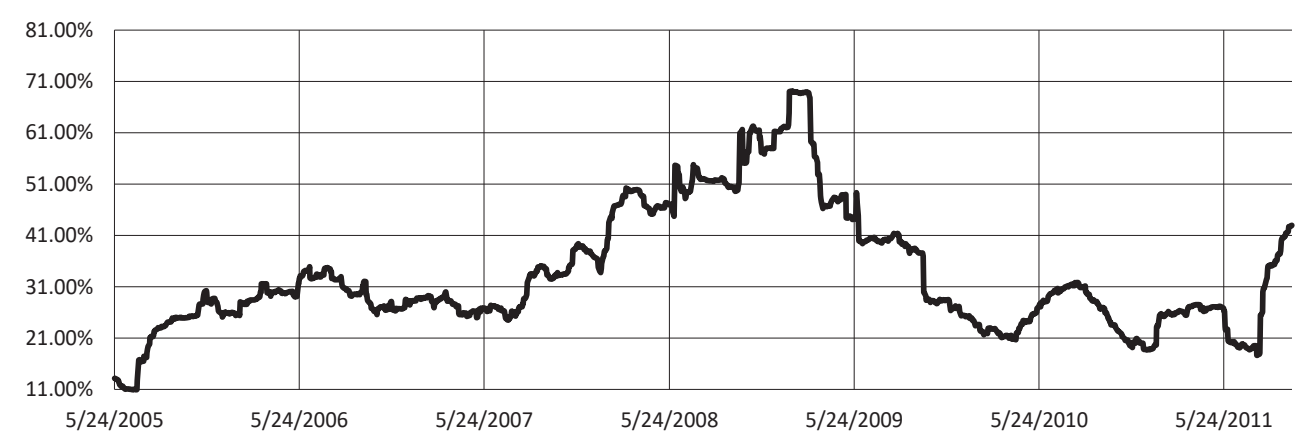

Fig. 5. Fluctuations of the volatility of stock prices for Apator in 2005-2011 (the vertical axis shows the annual standard deviation of the stock returns, and the horizontal axis - time)

Source: own work.

Another example of MA100 of the historical volatility over time was presented for Wawel company in Figure 6. Such an analysis was made for all companies in the sample.

Based on the time series of volatility for Wawel presented in Figure 3b, the histogram shown on Figure 7 was created and used as a template for creating the generator. After the creation of the generator with Excel, a quality test was made proving that the distribution from the generator is similar to the histogram in $\mathrm{Fi}$ gure 7. 


\section{Sigma Annual MA(100) 2005-2011}

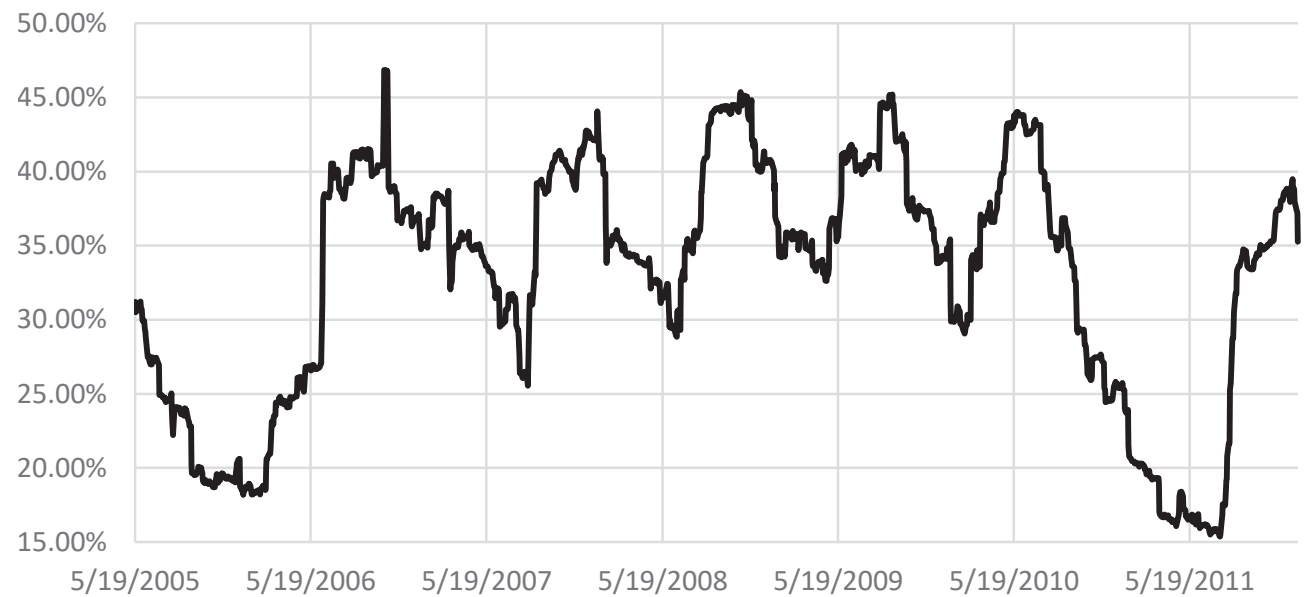

Fig. 6. Fluctuations of the volatility of stock prices for Wawel in 2005-2011 (the vertical axis shows the annual standard deviation of the stock returns, and the horizontal axis - time)

Source: own work

\section{Sigma MA(100) Annual \& Historical (2005-2011)}
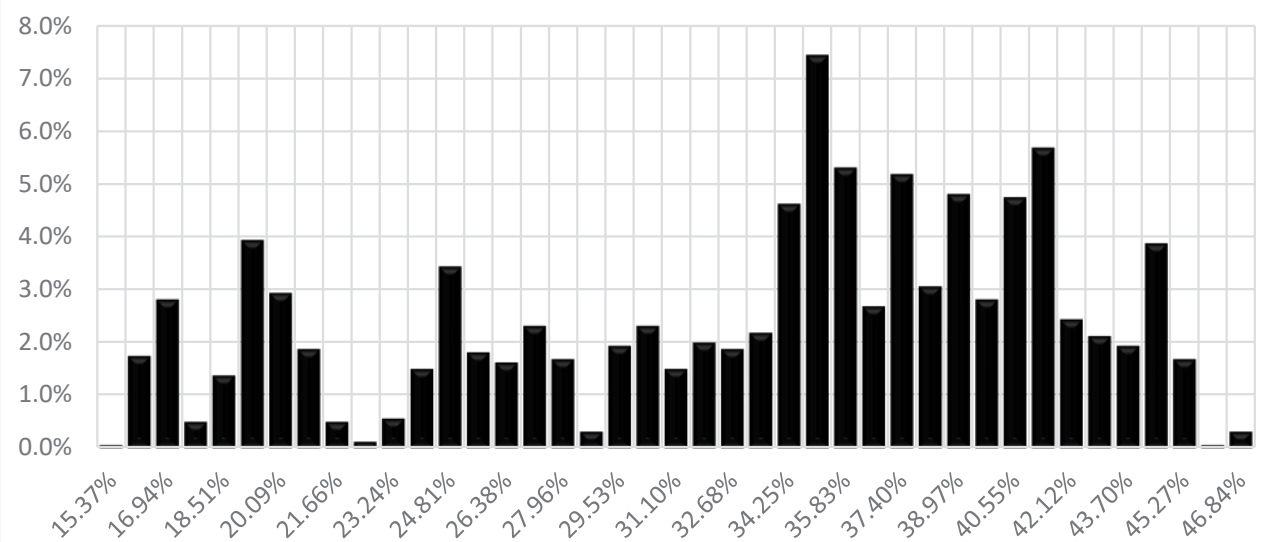

Fig. 7. Real distribution of volatility of the stock prices for Wawel in 2005-2011 (the vertical axis shows the density probability, and the horizontal axis - annual standard deviation of the stock returns)

Source: own work.

The generator of volatility was built based on the historical analysis of the annual standard deviation of rate of returns for stock prices.

The created distribution of the volatility by the generator as shown in Figure 8, has a similar profile as the real distribution shown in Figure 7. The generated volatility 


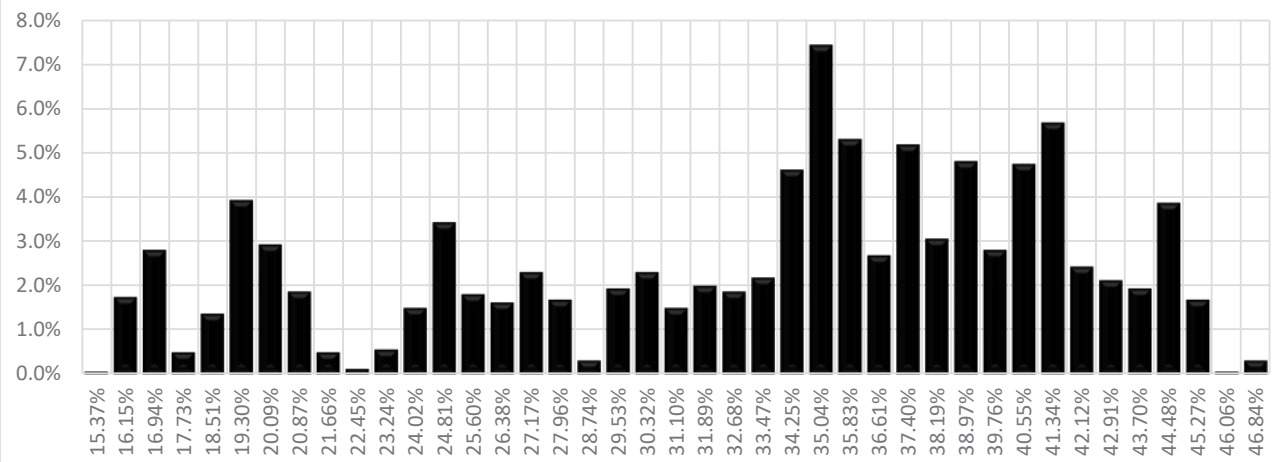

Fig. 8. Distribution created by the generator based on the real distribution of volatility of the stock prices for Wawel in 2005-2011 (the vertical axis shows the density probability, and the horizontal axis - annual standard deviation of the stock returns)

Source: own work.

distribution was used as the input to the binominal model to run the MCS, which resulted in obtaining the distribution of the equity for Wawel is shown as an example in Figure 9.

Equity Value E48(FV) Mln PLN



Fig. 9. The distribution of equity after MCS in the BM in the horizon of 8 years for Wawel (the vertical axis shows the density probability, and the horizontal axis - the value of the equity)

Source: own work. 
Based on the distribution shown in Figure 9, the range of modeled equity was established and then used to compare with the market value of equity, to compute error and the discrepancy with the modelled equity and market equity. It is worth highlighting that the distribution of the equity value was obtained from MC based on the BM. There is no such thing as a distribution of the real value, because on the market at the date of forecast there is only one market value, which is compared in the Back-Test with the range obtained from the forecast in the BM.

For research purposes the author created generators of all the companies real volatility distributions to run the MC simulation in the Binominal Model. Therefore, Wawel was shown as an example to prove the quality of generator. To obtain the high quality of generated volatility distribution, it was needed to run around 100000 simulations. With only 1000 simulations the difference between the profile of real volatility distribution and the generated one would not be acceptable.

\section{Presentation and analysis of the research results}

There are many positive results based on the research studies performed on the sample of the ten companies from Warsaw Stock Exchange. The BM supported with the Monte Carlo simulation based on the real volatility distribution delivered high accuracy in the medium horizon from 4 to 6 years. Average accuracy was observed for 3 and 7 years, low accuracy for 8 years and very low accuracy for the short horizon from 1 to 2 years. In $80 \%$ of cases, the equity value was overestimated by $+23.4 \%$ or underestimated by $-16.2 \%$. An accurate estimation with the BM, was observed in $20 \%$ of cases, which means that the market value of equity ties in with those forecasted by the BM. On average the estimation error was $+7.2 \%$, which seems to be very attractive for practical applications, since a forecast deviating by $7.2 \%$ from the market value provides investors and management with very a satisfactory tool supporting the decision-making processes. Figure 10 presents the estimation error in respect of time $(E E=f(t))$, where EE stands for estimation error. From this figure, the estimation errors in time horizon of 4 to 6 years are close to zero.

In Figure 11 the coefficient of variation in respect of time $\operatorname{Cof} V=f(t)$ was presented for distribution of equity in the BM. The coefficient of variation was defined as the relation between the standard deviation of the forecasted equity to the average value of the forecasted equity in the sample under consideration (in other words, it is a quotient of the standard deviation of the forecasted equity to the average forecasted equity in the sample under consideration). The coefficient of variation indicates that the estimated value of equity deviated from the mean. On average this coefficient equalled $6.9 \%$, which is very low if one realizes that the variation of the forecasted value of equity in a long horizon deviates only not as much. 


\section{Estimation Error over Time $E E=f(t)$}

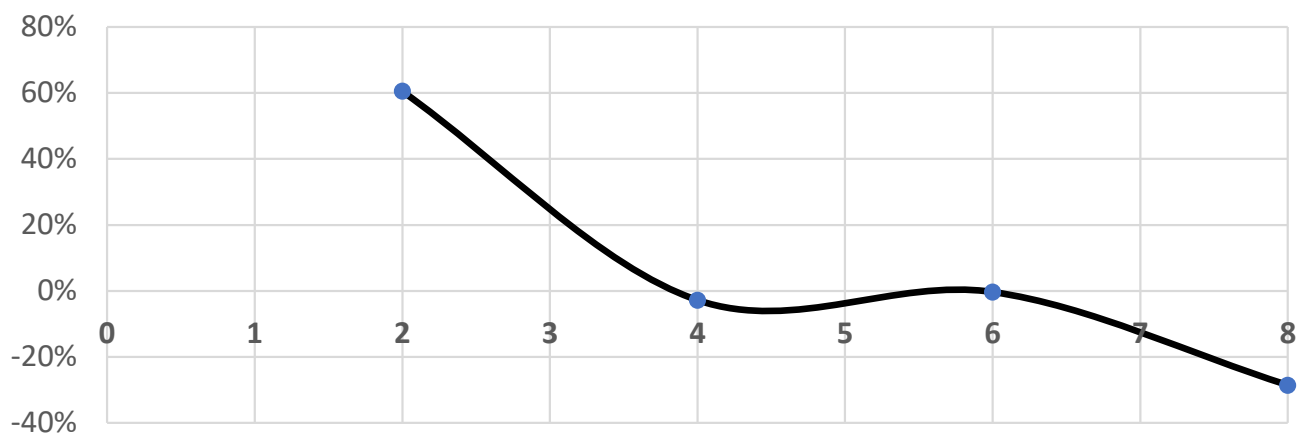

Fig. 10. The estimation error in the $B M$ in respect of time $E E=f(t)$ (the vertical axis shows the estimation error, and the horizontal axis - time horizon as the subsequent years in the BM)

Source: own work.

$$
\operatorname{CofV}=f(t)
$$

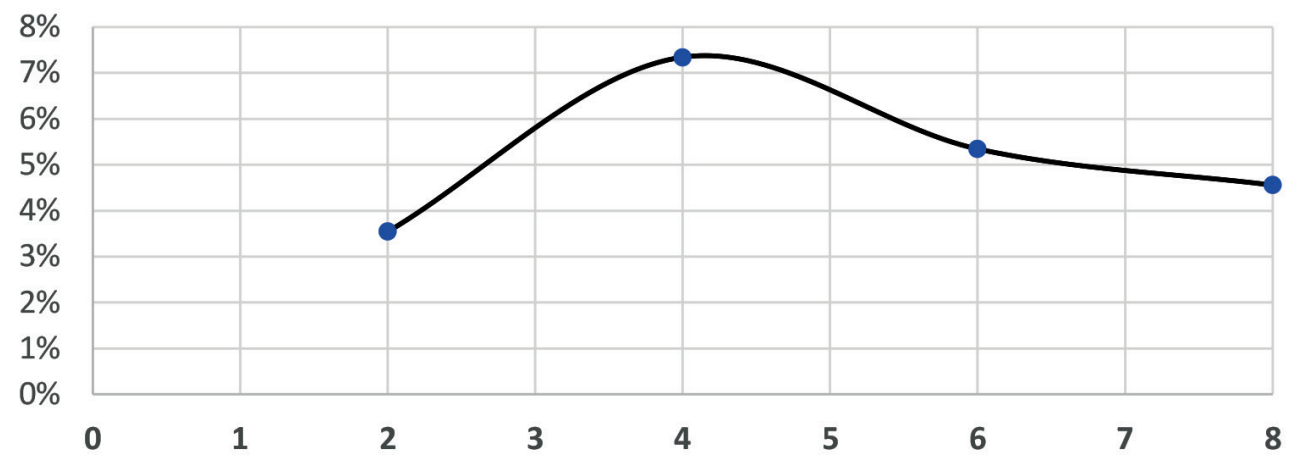

Fig. 11. The variation coefficient in the $B M$ in respect of time $E E=f(t)$ (the vertical axis shows the estimation error, and the horizontal axis - time horizon as the subsequent years in the BM)

Source: own work.

The positive results indicate the high quality of the BM, but this was very much because the Monte Carlo simulation was applied with real distributions volatility supported with volatility's distribution generators built in the Excel model. Building the generators is in fact a time-consuming process but it is worthwhile indeed.

Table 2 presents the estimation errors for all the companies in the research sample, namely how accurately the model was able to forecast on average. The average forecast accuracy was calculated for entire period, from a 1 to 8 year horizon. Error Under the Range (EUR) means that the BM overestimated the real market value, while Error Over the Range (EOR) means that the BM underestimated the real 
Table 2. The estimation errors and coefficients of variations of the BM for all companies in the sample

\begin{tabular}{|c|c|c|c|}
\hline No. & Name of the Company & Average CofV & Average Estimation Error (EUR if negative) (EOR if positive) \\
\hline 1 & Żyiec & $4.4 \%$ & $-42.0 \%$ \\
\hline 2 & Wawel & $3.4 \%$ & $62.7 \%$ \\
\hline 3 & KGHM & $3.2 \%$ & $-52.1 \%$ \\
\hline 4 & Dębica & $7.7 \%$ & $10.3 \%$ \\
\hline 5 & Ropczyce & $13.5 \%$ & $15.6 \%$ \\
\hline 6 & Stalprodukt & $3.1 \%$ & $39.3 \%$ \\
\hline 7 & Amica & $6.1 \%$ & $48.7 \%$ \\
\hline 8 & Śnieżka & $3.9 \%$ & $23.3 \%$ \\
\hline 9 & Budimex & $19.0 \%$ & $27.8 \%$ \\
\hline 10 & Apator & $17.0 \%$ & $4.7 \%$ \\
\hline & Total Average & $\mathbf{8 . 1} \%$ & $\mathbf{1 3 . 8 \%}$ \\
\hline
\end{tabular}

Source: own work.

market value. On average, for all the companies the BM underestimated by $13.8 \%$, which suggests quite high quality. For three companies, the model overestimated the market value, and for eight companies underestimated it. Table 2 also presents the coefficients of variation (CofV) for all the companies in the sample. They indicate how much the value of the equity forecasted by the BM deviated from its average, which reflects the width of the distribution of the forecasted equity. On average, for all the companies the standard deviation of the equity was $8.1 \%$ of the average value, which seems to be a very small spread, and indicates high accuracy.

\section{Conclusion}

The increasing expectations of higher accuracy in forecasting the value of a company create a challenge for building models able to manage this issue, therefore the study proposed a certain approach by putting together the Binominal Model Simulated with the Real Volatility Distribution, abbreviated as BIMSERVED. The accuracy in forecasting company equity in the time horizon from 1 to 8 years was on average at $13.8 \%$, which seems to be very precise. The coefficient of deviation in forecasted equity was on average $8.1 \%$, which points to very smooth distribution of equity due to applying the generator of real volatility distribution, created based on the 100 days moving average standard deviation of rates of returns to run the Monte Carlo simulation. There are no examples in the literature of the combined and parallel application tools such as the proposed BIMSERVED, and those especially supported by real volatility distribution. This approach is very time consuming, which is the reason why research by other authors using Monte Carlo simulations was limited to the typical and theoretical type of distributions. The BIMSERVED including the Back-Test, reflects the originality of the approach compared to the other findings in literature, which after this pilot study will be tested in a different context to prove its 
quality. The BIMSERVED model may greatly attract interest of managers and other practitioners, who need to cope with the demand for high accuracy of forecasted company value, which may help in the decision-making process as to shaping the company activity to increase the value for future sales transactions and stakeholder value. The benefits out of this method may be enjoyed by practitioners engaged in the analytical process of company valuation at the stages of restructuring, merging and acquisition, and building an investment portfolio. The group of interested entities may include banks, investment funds, consulting companies, investment advisors and corporations. This is a pilot study because there were only ten companies in the research sample from one country, which is not representative from statistical point of view. Another limitation is related to the assumption about company debt, which was forecasted in this model as a linear trend based on the historical data. Future studies should assume the debt value as being stochastically driven with the variance inferred from volatility of company value coming from the Ito concept. In this paper the author mainly focused on the application of the BIMSERVED model, which after this initial study will be more deeply verified. Future research will replicate studies on forecasting the equity value based on sampled companies from many European and global markets. he BIMSERVED model will be expanded for testing the future performance of companies, investment funds and indexes operating on the Environment-Social-Government (ESG) concept. This type of companies show very stable growth, therefore the BIMSERVED model may potentially deliver very high accuracy of forecasts by measuring the efficiency of these types of stocks.

\section{References}

Amram, M., \& Kutilaka, N. (1999). Real options, managing strategic investment in an uncertain world. Boston: Harvard Business School Press.

Black, F., \& Scholes, M. (1973, May-June). The pricing of options and corporate liabilities, Journal of Political Economy, 81, 640.

Brealey, R. A., Myers, S. C, \& Marcus, A. J. (2007). Osnove korporativnih financija, 5. izdanje. Zagreb: MATE.

Copeland, T., Koller, T., \& Murrin, J. (2000). Valuation - measuring and managing the value of companies. Hoboken: John Wiley \& Sons.

Copeland, T. E., \& Antikarov, V. (2001). Real options: A practitioners guide. New York: Texere.

Cox, J., Ross, S. A., \& Rubinstein, M. (1979). Option pricing: A simplified approach. Journal of Financial Economics, Rochester, 7(3), 229-263.

Damodaran, A. (2000). The promise of real options. Journal of Applied Corporate Finance, 13(2), 96.

Dixit, A. K., \& Pindyck, R. S. (1995, May-June). The options approach to capital investment, Harvard Business Review, 105-116.

Fenyves, V., \& Tarnoczi, T. (2010, December). Corporate valuation using two-dimensional Monte Carlo simulation. Retrieved from https://www.researchgate.net/publication/227462726 
Hussain, Z. (2019, December). Implementing Monte Carlo simulation model for revenue forecasting under the impact of risk and uncertainty. Management and Production Engineering Review, 10(4), 81-89. doi: 10.24425/mper.2019.131448

Jajuga, K., \& Krysiak, Z. (Eds.). (2005). Credit risk of mortgage loans - modelling and management (pp. 1-509). Polish Bank Association.

Kodukula, P., \& Papadesu, C. (2006). Project valuation using real options (pp. 70, 78, 79). Florida: J. Ross Publishing.

Krysiak, Z. (2015). Financial engineering in project development. Warsaw: Warsaw School of Economics.

Krysiak, Z., \& Pijanowski, S. (2015). Challenges and obstacles of ERM implementation in Poland. In J. R. S. Fraser, B. J. Simkins, \& K. Narvaez (Eds.), Implementing enterprise risk management case studies and best practices (pp. 577-606). Hoboken: John Wiley \& Sons.

Luehrman, T. A. (1998, July-August). Investment opportunities as real options: Getting started on the numbers. Harvard Business Review, (4), 10, 53, 139.

Mukhtar, W., \& Agarwal, R. K. (2009, November 7). DCF valuation of a firm: A case for application of Monte Carlo simulation. Retrieved from https://ssrn.com/abstract=1501589 or http://dx.doi. org/10.2139/ssrn.1501589

Mun, J. (2002). Real options analysis. Hoboken: John Wiley \& Sons.

Mun, J. (2006). Real option analysis; tools and tehniques for valuation strategic investments and decisions. Hoboken: John Wiley \& Sons.

Ross, S. A., Westerfield, R. W., \& Jaffe, J. (2005). Corporate finance, New York: McGraw-Hill Irwin.

Samis, M., \& Davis, G. (2014). Using Monte Carlo simulation with DCF and real options risk pricing techniques to analyse a mine financing proposal. Int. J. Financial Engineering and Risk Management, 1(3).

Seaman, S., \& Krysiak, Z. (2012). Equity based metrics used to model financial distress. Academy of Economics and Finance Journal, 3, 65-72.

Simkins, B., \& Narvaez, K. (2015). Implementing enterprise risk management - case studies and best practices. Hoboken: John Wiley \& Sons.

Schwartz, E. S., \& Trigeorgis, L. (2004). Real options and investment under uncertainty (pp. 1-5). The MIT Press.

Smit, H., \& Trigeorgis, L. (2006). Real options and games: Competition, alliances and other applications of valuation and strategy. Review of Financial Economics, (15), 96.

Tomas, I., \& Višić, J. (2020). Real option analysis - decision making in a volatile environment. Retrieved from https://bib.irb.hr/datoteka/430316

\section{DOKŁADNOŚĆ PROGNOZY KAPITALU W MODELU OPCJI Z SYMULACJĄ RZECZYWISTEJ ZMIENNOŚCI}

Streszczenie: Prezentowany artykuł poświęcony jest ocenie dokładności modelu dwumianowego w prognozowaniu wartości kapitału z wykorzystaniem metody Back-Test. W tym badaniu zastosowano metodę Monte Carlo do symulacji wartości kapitału z wykorzystaniem rzeczywistych rozkładów zmienności stóp zwrotu cen akcji. W oparciu o analizę profilu zmienności zbudowano generator rozkładów rzeczywistych, który wykorzystano do symulacji Monte Carlo. Wyniki badania potwierdziły wysoką jakość i dokładność proponowanej przez autora metody. Ze względu na potencjalnie duże korzyści dla zarządzających firmami i inwestorów, jakie płyną z jakości pomiaru, wg zaprezentowanej metody w badaniu, warto jest roszerzać ten nurt w teorii i praktyce. Artykuł skierowany jest głównie do praktyków zajmujących się analitycznym procesem wyceny przedsiębiorstwa przy restrukturyzacji, łączeniu i przejęciu przedsiębiorstwa oraz budowaniu portfela inwestycyjnego.

Słowa kluczowe: model opcyjny, model dwumianowy, symulacja Monte Carlo, rozkład rzeczywistych zmienności cen akcji, Beck-Test, prognoza kapitału przedsiębiorstwa. 